\title{
Bibliographical note
}

There is, as far as I am aware, no complete list of political apologies. A list compiled by G. Dodds entitled 'Political apologies: chronological list' covers the period to 2002 and can be accessed at http://reserve.mg2.org/apologies. htm. The appendix to Nobles, The Politics of Official Apologies lists apologies up to mid-2005. There is a website link to various articles and research about apology administered by R. Howard-Hassmann at 'Political Apologies and Reparations', www.political-apologies.wlu.ca.

The following references provide further details concerning case studies mentioned in the text. Where short titles are used, the full reference is in the Bibliography.

\section{Australia}

Augoustinos and LeCouteur, 'On Whether to Apologise to Indigenous Australians'; Augoustinos et al., 'Apologizing for historical injustice'; Barkan, The Guilt of Nations; Celermajer, 'The Apology in Australia'; Celermajer, The Sins of the Nation; K. Rudd, 'Fourth Anniversary of the National Apology to Indigenous Australians'.

Blair and Famine

Cunningham, 'Apologies in Irish politics: a commentary and critique'.

Bloody Sunday

D. Cameron, House of Commons Statement, Hansard, $6^{\text {th }}$ series, vol. 511, cols 734-61, 15 June 2010; J. Campbell, The Inside Story of the Bloody Sunday Justice Campaign (Dublin: Liberties Press, 2012); B. Conway, Commemoration and Bloody Sunday: Pathways of Memory (Basingstoke: Palgrave Macmillan, 
2010); D. Murray, Bloody Sunday: Truth, Lies and the Saville Inquiry (London: Biteback Books, 2012).

\section{Canada}

S. Harper, 'Prime Minister Stephen Harper's statement of apology', 11 June 2008, www.cbc.ca/news/canada/story/2008/06/11 pm-statement.html, accessed 6 March 2013; James, 'Wrestling with the Past'; Nobles, The Politics of Official Apologies.

\section{Chirac and France}

Celermajer, The Sins of the Nation; Fette, Apologizing for Vichy in Contemporary France'; J. Fette, 'The Apology Moment: Vichy Memories in 1990s France', 259-85 in Barkan and Karn (eds), Taking Wrongs Seriously.

\section{Clinton apologies}

Cunningham, 'Mea Culpa (almost)'; Dawson and Popoff, 'Reparations: justice and greed in black and white'; Gibney and Roxstrom, 'The status of state apologies'; Negash, Apologia Politica; Smith, I Was Wrong.

\section{Germany}

Barkan, The Guilt of Nations; C. Goschler, 'Disputed victims: the West German Discourse on Restitution for the Victims of Nazism', 93-110 in Berg and Schaefer (eds), Historical Justice in International Perspective; Jones, 'Apology diplomacy: justice for all?'; Lind, Sorry States; Löwenheim, 'A haunted past'; Negash, Apologia Politica; Renner, “I'm sorry for apologising”.

\section{Hillsborough}

House of Commons. Hansard $6^{\text {th }}$ Series, vol. 550, cols 283-306, 12 September 2012. House of Commons. Hansard $6^{\text {th }}$ series, vol. 551, cols 719-804, 22 October 2012. 'The Report of the Hillsborough Independent Panel', HC581, The Stationery Office, London, 2012 (http://hillsborough.independent. gov.uk/repository/report/HIP-report); P. Scraton, Hillsborough: The Truth (Edinburgh: Mainstream, 2nd edn, 2009).

\section{Japan}

Barkan, The Guilt of Nations; Coicaud, 'Apology: a small yet important part of justice'; Cunningham, 'Prisoners of the Japanese and the politics of apology'; Dahl, 'Is Japan facing its past?'; Dudden, Troubled Apologies; Lind, Sorry States: Apologies in International Politics; Negash, Apologia Politica; Yamazaki, Japanese Apologies for World War II. 
Japanese-American internees

Barkan, The Guilt of Nations, in Brooks (ed.), When Sorry Isn't Enough, Part 4 'Japanese Americans'; Weiner, The Sins of the Parents; Weyeneth, 'The power of apology and the process of historical reconciliation'.

Katyn

BBC, 'Russian parliament condemns Stalin for Katyn massacre', www.bbc. co.uk/news-europe-11845315, accessed 15 January 2013; A. M. Cienciala, N. S. Lebedeva and W. Materski (eds), Katyn: A Crime without Punishment (New Haven, CT: Yale University Press, 2007); A. Paul, Katyn: Stalin's Massacre and the Triumph of Truth (DeKalb, IL: Northern Illinois University Press, 2010); G. Sanford, Katyn and the Soviet Massacre of 1940: Truth, Justice and Memory (London: Routledge, 2005).

\section{Serbia}

BBC, 'Serbian MPs offer apology for Srebenica massacre', 31 March 2010, http:// news.bbc.co.uk/1/hi/world/europe8594625.stm, accessed 18 January 2013; Denti, 'Public apologies in the Western Balkans'; T. Judah, The Serbs: History, Myth and the Destruction of Yugoslavia (New Haven, CT: Yale University Press, $3^{\text {rd }}$ edn, 2009); New York Times, 'Serbia’s Honest Apology', http//nytimes.com/2010/04/02opinion/02/Judah.html, accessed 18 January 2013.

\section{Slavery}

Berg, 'Historical Continuity and Counterfactual History in the Debate over Reparations for Slavery', in Brooks (ed.), When Sorry Isn't Enough, Part 6 'Slavery'; Brooks, 'The New Patriotism and Apology for Slavery'; Dawson and Popoff, 'Reparations: justice and greed in black and white; du Plessis, 'Historical injustice and international law: an exploratory discussion of reparation for slavery'; Fleming, 'When Sorry is Enough'; Pettigrove, 'Apology, reparations and the question of inherited guilt'; E. Posner and A. Vermeule, 'Reparations for slavery and other historical injustices', Columbia Law Review, 103:3 (2003), 689-747; Torpey, 'Paying for the past?'; Weyeneth, 'The power of apology and the process of historical reconciliation'.

\section{'Tuskegee'}

W. Clinton 'Remarks by the President in apology for study done in Tuskegee', 16 May 1997, http://clinton4.nura.gov/textonly./New/Remarks.Fri/19970516898.html, accessed 18 June 2009; J. Jones, Bad Blood: The Tuskegee Syphilis Experiment (New York: Free Press, 1981); S. M. Reverby (ed.), Tuskegee's 
Bibliographical note

Truths: Rethinking the Tuskegee Syphilis Study (Chapel Hill, NC: University of North Carolina Press, 2000). 